\title{
Combining forest structure data and fuel modelling to classify fire hazard in Portugal
}

\author{
Paulo M. FERNANDES* \\ Centro de Investigação e de Tecnologias Agro-Ambientais e Biológicas (CITAB) and Departamento Florestal, Universidade de Trás-os-Montes e \\ Alto Douro, Apartado 1013, 5001-801 Vila Real, Portugal
}

(Received 24 January 2008, revised version 2 August 2008; accepted 16 December 2008)

Keywords:

fuel modelling /

Mediterranean-type ecosystems /

fire hazard /

fire behaviour simulation

Mots-clés :

modélisation du combustible /

écosystèmes de type méditerranéen /

risque d'incendie /

simulation du comportement du feu

\begin{abstract}
- Fire management activities can greatly benefit from the description of wildland fuel to assess fire hazard.

- A forest typology developed from the Portuguese National Forest Inventory that combines cover type (the dominant overstorey species) and forest structure defined as a combination of generic stand density (closed or open) and height (low or tall) is translated into fuel models. Fire behaviour simulations that accounted for the fire environment modification induced by stand structure resulted in an objective and quantitative assessment of fire hazard for 19 forest types.

- The range of fire risk is similar between and within cover types. Stand structure, rather than cover type, is the major determinant of fire vulnerability. This indicates a potentially prominent role of stand and fuel management in wildfire mitigation. Four fire hazard groups are defined: (1) open and tall forest types, and closed and tall Quercus suber and diverse forests; (2) closed, low woodlands of deciduous oaks, $Q$. suber and diverse forests, closed and tall Pinus pinaster woodland and tall Eucalyptus globulus plantations; (3) open and low forest types; (4) dense low stands of P. pinaster, E. globulus and Acacia. Potential fire risk increases from (1) to (4).
\end{abstract}

Résumé - Combinaison des données de structure forestière et de modélisation de la disponibilité en combustible pour classer les risques d'incendie de forêt au Portugal.

- Les activités de gestion des risques d'incendie peuvent grandement bénéficier de la description du combustible forestier.

- Une typologie forestière développée à partir de l'Inventaire Forestier National Portugais combinant type de couvert (espèces de l'étage dominant) et structure de la forêt définie comme une combinaison de la densité générique du peuplement (fermé ou ouvert) et de la hauteur (haute ou basse) est traduite en modèles de disponibilité en combustible. Les simulations de comportement du feu prenant en compte les modifications induites par la structure des peuplements ont abouti à une évaluation objective et quantitative des risques d'incendie pour 19 types de forêts.

- La gamme de risques d'incendie est similaire entre et dans les types de couvert. La structure des peuplements, plutôt que le type de couvert, est le principal déterminant de la vulnérabilité à l'incendie, ce qui indique un rôle potentiellement important de la gestion des peuplements et du combustible dans la lutte contre les feux de forêts. Quatre groupes de risque d'incendie sont distingués : (1) forêts hautes et ouvertes, et couverts fermés et hauts de Quercus suber; (2) peuplements bas et fermés de chênes décidus, de $Q$. suber et de diverses essences, grands bois fermés de Pinus pinaster et plantations de grands Eucalyptus globulus; (3) forêts ouvertes et basses; (4) peuplements bas et denses de P. pinaster, E. globulus et Acacia. risque potentiel d'incendie s'accroît de (1) à (4).

\section{INTRODUCTION}

Wildland fire is an acute problem in the Mediterranean Basin. European forest fire management agencies strive for

\footnotetext{
* Corresponding author: pfern@utad.pt
}

preventing and extinguishing fires in order to safeguard human life, property and natural resources. While this strategy can tackle the overwhelming majority of fires, its results are compromised when a fire escapes initial attack and develops into a large conflagration. In Portugal, for example, wildfires larger than 100 ha in size are no more than $1 \%$ of the number of fire 
events but account for ca. 75\% of the total area burned (DGRF, 2006). Regardless of the capacity and amount of resources available for fire suppression (Hirsch and Martell, 1996), its effectiveness is limited by the fire environment, or the factors - weather, topography, and the properties of vegetation as a fuel - that determine fire behaviour, i.e. the physical determinants of fire spread and heat release rates (Countryman, 1974). Of these influences, only fuel can be addressed by management actions, which makes its treatment at the stand and landscape levels the cornerstone of a proactive approach to wildfire mitigation (Agee and Skinner, 2005; Fernandes and Botelho, 2003). Given the key role of fuel in fire behaviour and effects, its characterization is of paramount importance to the overall wildland fire management process.

Wildland fuel complexes assemble distinct individual elements and strata, and as a result are highly variable in nature and composition, as well as in structure and spatial organization (Brown, 1981). Systematic schemes of fuel classification are therefore needed to describe fuel consistently, without oversimplification, and for a variety of users and objectives (Sandberg et al., 2001). Fuel characterization and classification leads itself to the assessment of fire hazard, which in the context of fire risk analysis generically refers to the potential fire behaviour for a vegetation type (Bachmann and Allgöwer, 2000; Hardy, 2005) and is more objectively appraised by mathematical modelling (Alexander, 2007).

Fuel description and classification typologies depend on the input requirements of the models used to estimate fire behaviour characteristics. Rothermel (1972) designed the fuel model concept to feed his semi-physical fire spread model with quantitative fuel data, considering four possible vectors for surface fire propagation (litter, herbs, shrubs, slash) and resulting in the so-called NFFL stylised fuel models (Anderson, 1982). Further technological developments (Andrews et al., 2005; Burgan and Rothermel, 1984) have allowed users to build and test custom fuel models to obtain more realistic estimates of fire characteristics for their specific fuel types.

European fuel types are frequently assigned a NFFL fuel model, e.g. ICONA (1990). This is understandable, given the existence of ready to use technology and training, lack of expertise in advanced fuel modelling, and because the fuel models are usually employed to assess possible or potential, rather than actual, fire situations. The need to address the specificities of Mediterranean well-aerated, heterogeneous and very fine fuel complexes is nevertheless well recognised, and has prompted several research efforts on the properties of fuel particles (Cohen et al., 2003) and fuel beds (Allgöwer et al., 2004) for the more widespread species and vegetation cover types. Custom fuel models in Europe have been developed to describe local conditions, usually to rate and map fuel hazard or for research purposes, namely to quantify the effects of fuel management activities on fire hazard (e.g., Fernandes and Botelho, 2004) and to model fuel accumulation and fire behaviour with time (e.g., Fernandes and Rigolot, 2007). Other European studies have proposed fuel models for broader regional or national application, namely in Switzerland (Allgöwer et al., 1998), Greece (Dimitrakopoulos, 2002) and Portugal (Cruz, 2005; Cruz and Fernandes, 2008).
Forest inventory data has proved helpful in fuel modelling (e.g., Cruz et al., 2003), hazard classification and mapping (e.g., Hardy et al., 2001) and modelling of post-fire tree survival (González et al., 2007a). The hypothesis examined in this study is whether standard forest inventory data can be used to assess fire hazard. The forest classification used in the Portuguese National Forest Inventory (NFI) is translated into fuel models, which are then used to evaluate and compare the fire hazard potential between and within forest types defined by their composition and structure.

\section{METHODS}

\subsection{Fuel modelling}

The NFI includes variables that describe the vertical structure and composition of Portuguese mainland forests on 2258 sampling plots (DGF, 2001). The NFI field assessments aimed at describing forest composition and vertical structure consists of percentage cover estimates by species or groups of analogous species per height class. Seven layers are considered, respectively $<0.5 \mathrm{~m}, 0.5-1 \mathrm{~m}, 1-2 \mathrm{~m}$, 2-4 m, 4-8 m, 8-16 m, and > $16 \mathrm{~m}$.

Godinho-Ferreira et al. (2005) divide the Portuguese mainland forest in 10 cover types, as defined by the dominant species: Quercus pyrenaica, other deciduous oaks ( $Q$. robur and $Q$. faginea), Arbutus unedo, Cistus ladanifera, Cytisus spp., Acacia spp., Quercus suber, Pinus pinaster, Eucalyptus globulus, and diverse forests. Four species occupy ca. $80 \%$ of the forested surface: $P$. pinaster (maritime pine) and E. globulus (blue gum) prevail in the northern half of the country, while Quercus suber (cork oak) and Q. rotundifolia (holm oak) respectively dominate the southwest and the southeast.

Forest structure in the NFI is simply categorized in two general classes for both density and height that allows four possible combinations, respectively open and tall, open and low, closed and tall, and closed and low forest. The existing variability in composition and structure in the NFI database was statistically summarized by Godinho-Ferreira et al. (2005) by means of a cluster analysis that resulted in the discrimination of 22 forest types. The correspondence between cover types and structural categories is displayed in Table I. The fuel modelling process consisted in estimating fuel parameters for each of the forest types defined by Godinho-Ferreira et al. (2005). Arbutus pre-forest and shrub-dominated (Cytisus and Cistus) cover types with scattered trees were not considered, since our interest was to appraise fuel hazard in strict forest ecosystems. Additional information about the depth and cover of litter in the NFI plots was retrieved from the NFI database and averaged for each forest type.

The first step in fuel models development was to collect in the literature the fuel properties of the species identified by the NFI that generate the forest floor and comprise the understorey vegetation layers. The following variables are required to run the surface fire spread model of Rothermel (1972): surface area to volume ratio and heat content of the particles, fuel load by size class and dead or live condition, dead fuel moisture of extinction, and fuel depth. Fuel load was estimated from bulk density, i.e. biomass quantity per unit of occupied volume. The compilations of Cohen et al. (2003) and Silva (2006) were the main data sources used. In the absence of information for a given species, the fuel characteristics of a similar species or the mean value for a group of related species were assumed. 
Table I. Fuel model parameters for the 19 forest types.

\begin{tabular}{|c|c|c|c|c|c|c|c|c|c|c|}
\hline \multicolumn{2}{|c|}{ Cover and structural type } & \multirow{2}{*}{$\begin{array}{c}\text { Depth, } \\
\mathrm{cm}\end{array}$} & \multicolumn{4}{|c|}{ Fuel load, $\mathrm{t} \mathrm{ha}^{-1}$} & \multirow{2}{*}{$\begin{array}{c}\text { SVR, } \\
\mathrm{m}^{-1}\end{array}$} & \multirow{2}{*}{$\begin{array}{c}\mathrm{HC}, \\
\mathrm{kJ} \mathrm{kg}^{-1}\end{array}$} & \multirow{2}{*}{$\begin{array}{c}\mathrm{Mx}, \\
\%\end{array}$} & \multirow[t]{2}{*}{ WAF } \\
\hline & & & $1 \mathrm{~h}$ & $10 \mathrm{~h}$ & $100 \mathrm{~h}$ & live & & & & \\
\hline Acacia spp. & CL & 43 & 5.17 & 1.51 & 0.00 & 3.47 & 5214 & 20267 & 32 & 0.17 \\
\hline \multirow[t]{4}{*}{ Eucalyptus globulus } & OT & 16 & 1.10 & 1.98 & 1.03 & 0.49 & 3645 & 21032 & 27 & 0.14 \\
\hline & OL & 51 & 1.33 & 0.41 & 0.00 & 1.18 & 5764 & 20904 & 30 & 0.23 \\
\hline & CT & 28 & 5.16 & 2.84 & 1.25 & 2.15 & 5752 & 20979 & 28 & 0.10 \\
\hline & CL & 57 & 3.73 & 0.50 & 0.00 & 4.02 & 5579 & 20897 & 30 & 0.13 \\
\hline Quercus pyrenaica & $\mathrm{CL}$ & 69 & 1.60 & 0.59 & 0.17 & 2.48 & 5497 & 19804 & 26 & 0.12 \\
\hline Other deciduous oaks & $\mathrm{CL}$ & 43 & 6.37 & 0.59 & 0.17 & 4.89 & 5039 & 19604 & 25 & 0.14 \\
\hline \multirow[t]{4}{*}{ Diverse } & OT & 17 & 2.05 & 0.41 & 0.00 & 0.42 & 7119 & 20531 & 26 & 0.19 \\
\hline & $\mathrm{OL}$ & 39 & 1.73 & 0.22 & 0.00 & 1.17 & 4720 & 20491 & 28 & 0.36 \\
\hline & CT & 39 & 2.55 & 1.97 & 0.28 & 1.41 & 4772 & 20467 & 28 & 0.13 \\
\hline & $\mathrm{CL}$ & 58 & 1.91 & 1.03 & 0.00 & 3.56 & 5318 & 20453 & 32 & 0.17 \\
\hline \multirow[t]{4}{*}{ Pinus pinaster } & OT & 12 & 5.32 & 2.97 & 1.16 & 0.90 & 4551 & 21388 & 38 & 0.17 \\
\hline & OL & 36 & 1.86 & 1.03 & 0.00 & 2.36 & 4303 & 21444 & 36 & 0.44 \\
\hline & CT & 24 & 7.36 & 2.81 & 0.88 & 3.04 & 4986 & 21236 & 37 & 0.12 \\
\hline & $\mathrm{CL}$ & 46 & 6.66 & 0.89 & 0.21 & 6.35 & 4950 & 21273 & 36 & 0.16 \\
\hline \multirow[t]{4}{*}{ Quercus suber } & OT & 41 & 1.38 & 0.18 & 0.00 & 0.56 & 5994 & 20412 & 28 & 0.16 \\
\hline & OL & 50 & 1.28 & 2.52 & 0.00 & 1.00 & 5304 & 20390 & 32 & 0.36 \\
\hline & CT & 17 & 3.29 & 1.90 & 0.00 & 1.19 & 5583 & 20458 & 22 & 0.12 \\
\hline & $\mathrm{CL}$ & 39 & 4.75 & 1.55 & 0.00 & 4.39 & 4666 & 20381 & 25 & 0.15 \\
\hline
\end{tabular}

$\mathrm{CL}=$ closed and low stands; $\mathrm{CT}=$ closed and tall stands; $\mathrm{OL}=$ open and low stands; OT $=$ open and tall stands; $1 \mathrm{~h}, 10 \mathrm{~h}$ and $100 \mathrm{~h}$ respect to dead fuel with diameters $<6 \mathrm{~mm}, 6-25 \mathrm{~mm}$, and $>25 \mathrm{~mm}$, respectively. SVR = surface area to volume ratio; $\mathrm{HC}=$ heat content; Mx = dead fuel moisture of extinction; WAF $=$ wind adjustment factor.

The information gathered by the literature review was combined with the NFI synthesized data for each forest type in order to (i) estimate fine fuel ( $<6 \mathrm{~mm}$ in diameter) load for each species and dead or live condition from the respective volumes of occupation on each layer up to a 2-m height; and (ii) estimate means for the remaining fuel characteristics (surface area to volume ratio, heat content, dead fuel moisture of extinction) for each layer, where the value of each species was weighted by the relative quantity of the species in the fuel layer.

Loadings of coarse (thicker than $6 \mathrm{~mm}$ ) dead fuel is also an input to Rothermel's model, although the significance of larger dimension fuel is usually reduced in Mediterranean forests. Because the NFI lacked the information necessary to derive the respective estimates, we assumed values from the literature (Cruz 2005; Cruz and Fernandes, 2008; Fernandes and Rigolot, 2007) and from destructive sampling in representative fuel types (unpublished data on file).

A fuel model was built for each of the 19 forest types by summarizing data according to the input requirements of the software Behave Plus 3.0 (Andrews et al., 2005). Fuel depth was computed as the sum of litter depth and understorey depth $H$, with $H$ determined as:

$$
H=h-h[(100-C) / 100]
$$

where

$h=$ mean understorey height

$C=$ understorey cover $\%$.

\subsection{Fire hazard assessment}

The basis to assess fire hazard was fire behaviour estimation via fuel models that express the physical properties of surface fuel as a whole. Implicit to each forest type is however a fire environment that integrates factors external to the surface fuel complex and further distinguishes the fire potential between types. The simulation of fire behaviour was therefore made more realistic by taking into account (i) the effect of stand structure on wind speed and dead fuel moisture, and (ii) the implications of species composition on the moisture content of live fuel.

Fire spread is driven by the within-stand surface wind, thus requiring a quantification of the canopy induced decrease in wind speed. Wind adjustment factors (WAF) to convert wind speed at the standard 6-m height above the vegetation to the so-called midflame wind speed were calculated following Finney (1998) from the mean overstorey height, crown ratio and crown cover of each forest type. WAF values are included in Table I and range from 0.10 to 0.44 .

Live fuel moisture values representative of the summer peak burning period were collected in the literature for the various species (Castro et al., 2006; Viegas et al., 1992; 2001) and complemented by information from UTAD's arboretum (unpublished data on file). Means for each forest type were separately calculated for the understorey vegetation and for tree foliage, weighing the individual species by their load and volume, respectively. A $75-106 \%$ interval covered the overall variation in live fuel moisture of the understorey, with the low and high extremes respectively corresponding to low and closed Quercus suber stands and deciduous oak woodland. Canopy foliage 
Spread rate

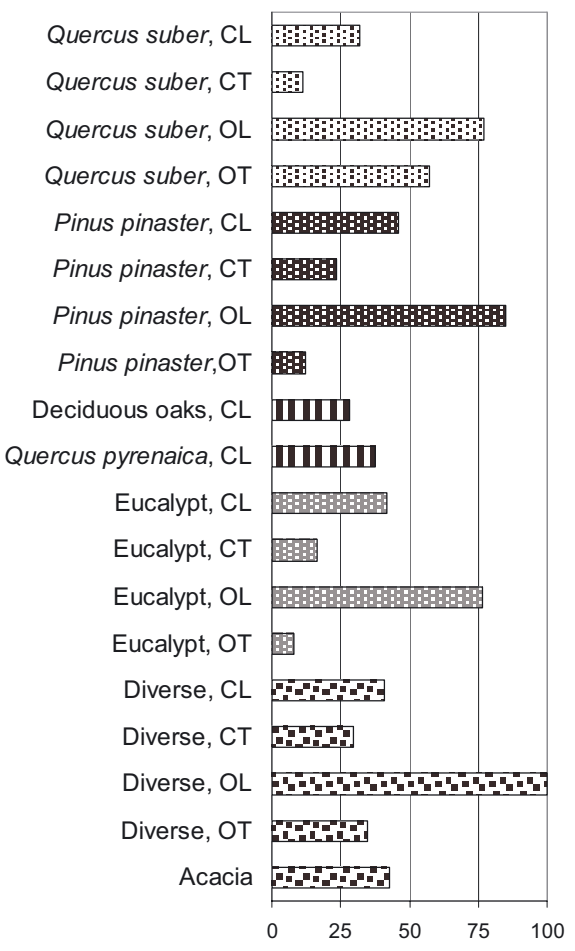

Intensity



Crowning
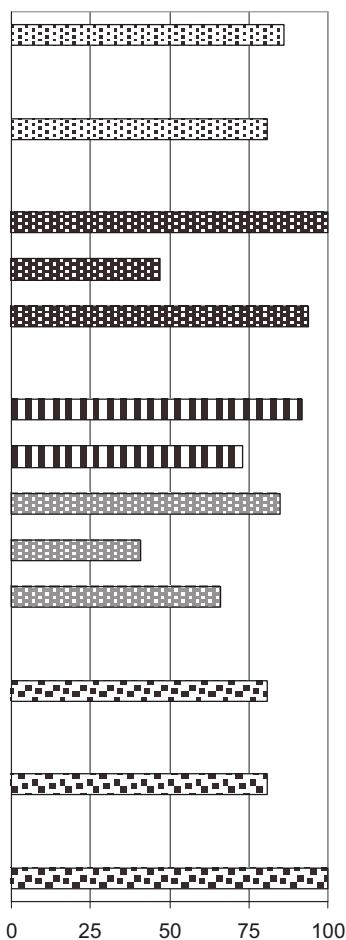

Figure 1. Fire hazard scores (0-100) for the 19 forest types.

moisture ranged from $90 \%$ in $Q$. suber types to $120 \%$ in eucalypt types.

The evaluation of fire hazard for the 19 forest types was based on three fire behaviour descriptors, respectively rate of spread, fireline intensity, and crown fire potential. For each fuel model the surface fire rate of spread was estimated with the model of Rothermel (1972), as implemented in Behave Plus 3.0 (Andrews et al., 2005), using as inputs a 6-m windspeed of $30 \mathrm{~km} \mathrm{~h}^{-1}$, the WAF, the moisture contents estimated for each fuel model, and a slope terrain of $30 \%$. It is under severe weather characterized by dry and windy conditions that most of the fires escaping initial attack occur and develop into landscape scale incidents. The choice of the weather scenario for fire simulation acknowledges this, while avoiding extreme, worst-case scenarios that are unlikely to happen across all country and all vegetation types. Estimation of dead fuel moisture contents proceeded according to Rothermel et al. (1986), allowing differentiation between forest types as a function of the WAF and several tree and stand structure descriptors, and using as weather inputs a relative humidity of $20 \%$, an ambient temperature of $35^{\circ} \mathrm{C}$, and a 6-m windspeed of $30 \mathrm{~km} \mathrm{~h}^{-1}$. Dead fuel moistures estimates varied in the relatively narrow range of 3.8 to $5.3 \%$; drier and moister fuel corresponding respectively to open, low forest types, and to dense, tall forests.

Fireline intensity sensu Byram (1959) was calculated by multiplying the rate of spread estimate, fuel load (i.e. assuming total fuel consumption), and heat content corrected for losses due to moisture content. The critical fire intensity for crown fire initiation was determined as a function of canopy base height and foliar moisture content (Van Wagner, 1977). The corresponding spread rate value was then calculated and the 6-m wind speed threshold for crowning was found in Behave Plus by plotting rate of fire spread over a reasonable wind speed range of $0-70 \mathrm{~km} \mathrm{~h}^{-1}$. This index of crowning potential is different from the Torching Index of Scott and Reinhardt (2001) as fireline intensity calculation differs.

Fire behaviour estimates were converted to relative indices given by $100 x_{\mathrm{i}} / x_{\max }$, where $x_{\mathrm{i}}$ is the value of variable $x$ in forest type $i$ and $x_{\max }$ is the maximum value of variable $x$, which resulted in scores on intervals of 10-100] for surface fire spread and intensity, and [0-100] for crowning ( 0 meaning a crown fire is unlikely). Overall fire hazard was categorized on the basis of a hierarchical cluster analysis on the fire hazard scores by using Ward's method (Johnson and Wichern, 1982).

\section{RESULTS AND DISCUSSION}

Table I displays the parameters for the fuel models and Figure 1 presents the three fire hazard components arising from the simulations. The developed fuel models have not undergone adjustment (e.g., Cruz and Fernandes, 2008; Hough and Albini, 1978) to match fire behaviour data. The objectives of the study are not compromised, since the fuel modelling methodology was objectively and consistently applied to all forest types, and because our concern was the description and comparison of fire potential in relative terms.

An obvious wide variation in fire potential exists among the 19 forest types (Fig. 1). The spread rate potential has a 13-fold 
Table II. Fuel descriptors (mean \pm std. dev.) with significant differences among cover types.

\begin{tabular}{|c|c|c|c|c|}
\hline Type & Understorey height $(\mathrm{m})$ & $\mathrm{HC}, \mathrm{kJ} \mathrm{kg}^{-1}$ & $\mathrm{Mx}(\%)$ & $\mathrm{M}_{\mathrm{L}}(\%)$ \\
\hline Acacia spp. & $1.3 \mathrm{ab}$ & $20236 \mathrm{a}$ & $32 a b$ & $99 a b$ \\
\hline Eucalyptus globulus & $0.9 \pm 0.3 \mathrm{ab}$ & $20963 \pm 85 b$ & $29 \pm 1 b$ & $91 \pm 7 b$ \\
\hline All deciduous oaks & $1.3 \pm 0.1 \mathrm{a}$ & $19717 \pm 154 \mathrm{c}$ & $25 \pm 1 b$ & $102 \pm 5 \mathrm{a}$ \\
\hline Diverse forests & $0.9 \pm 0.3 \mathrm{ab}$ & $20478 \pm 45 a$ & $29 \pm 1 b$ & $90 \pm 6 a b c$ \\
\hline Pinus pinaster & $0.7 \pm 0.2 b$ & $21340 \pm 110 a$ & $37 \pm 1 \mathrm{a}$ & $84 \pm 1 b c$ \\
\hline Quercus suber & $1.3 \pm 0.1 \mathrm{ab}$ & $20392 \pm 46 a$ & $27 \pm 4 b$ & $80 \pm 4 c$ \\
\hline
\end{tabular}

Means followed by the same letter in a column are not significantly different according to the HSD Tukey test.

$\mathrm{HC}=$ heat content; $\mathrm{Mx}=$ dead fuel moisture of extinction; $\mathrm{M}_{L}=$ live fuel moisture content.

Table III. Stand, fuel and fire hazard descriptors by structural forest type (mean \pm std. dev.).

\begin{tabular}{|c|c|c|c|c|c|c|}
\hline \multirow{2}{*}{ Type } & \multirow{2}{*}{ Crown cover $(\%)$} & \multirow{2}{*}{ Stand height (m) } & \multirow{2}{*}{ Crown base height (m) } & \multirow{2}{*}{ WAF } & \multicolumn{2}{|c|}{ Understorey } \\
\hline & & & & & height $(\mathrm{m})$ & cover $(\%)$ \\
\hline $\mathrm{CL}$ & $60 \pm 18 \mathrm{ab}$ & $6.0 \pm 0.4 \mathrm{a}$ & $2.9 \pm 0.7 \mathrm{a}$ & $0.15 \pm 0.02 \mathrm{a}$ & $1.1 \pm 0.2 \mathrm{a}$ & $49 \pm 12 \mathrm{a}$ \\
\hline $\mathrm{CT}$ & $84 \pm 10 a$ & $9.8 \pm 2.0 \mathrm{~b}$ & $5.3 \pm 0.9 \mathrm{~b}$ & $0.12 \pm 0.01 \mathrm{a}$ & $0.9 \pm 0.3 \mathrm{ab}$ & $24 \pm 9 b$ \\
\hline OL & $22 \pm 10 \mathrm{c}$ & $5.8 \pm 0.7 \mathrm{a}$ & $3.0 \pm 1.1 \mathrm{a}$ & $0.35 \pm 0.09 \mathrm{~b}$ & $0.8 \pm 0.1 \mathrm{~b}$ & $19 \pm 10 b$ \\
\hline OT & $44 \pm 10 \mathrm{bc}$ & $10.4 \pm 1.9 \mathrm{~b}$ & $6.3 \pm 0.8 \mathrm{~b}$ & $0.16 \pm 0.02 \mathrm{a}$ & $0.6 \pm 0.1 \mathrm{~b}$ & $9 \pm 4 b$ \\
\hline Type & \multicolumn{2}{|c|}{ Fine fuel } & Fuel depth $(\mathrm{cm})$ & \multicolumn{3}{|c|}{ Fire hazard score } \\
\hline $\mathrm{CT}$ & $6.6 \pm 3.0 \mathrm{ab}$ & $0.70 \pm 0.04 \mathrm{~b}$ & $27 \pm 9 b c$ & $20 \pm 8 a$ & $30 \pm 17 \mathrm{ab}$ & $22 \pm 25 b$ \\
\hline OL & $2.7 \pm 0.8 \mathrm{~b}$ & $0.48 \pm 0.11 \mathrm{a}$ & $44 \pm 8 \mathrm{ab}$ & $85 \pm 11 b$ & $48 \pm 15 \mathrm{ab}$ & $80 \pm 11 \mathrm{a}$ \\
\hline OT & $2.8 \pm 1.6 \mathrm{~b}$ & $0.77 \pm 0.07 b$ & $21 \pm 14 \mathrm{c}$ & $28 \pm 23 a$ & $14 \pm 6 b$ & $0 \pm 0 \mathrm{~b}$ \\
\hline
\end{tabular}

Means followed by the same letter in a column are not significantly different according to the HSD Tukey test.

$\mathrm{WAF}=$ wind adjustment factor.

variation, from open and tall eucalypt stands to open and low diverse woodland, and fireline intensity varies even more (18fold), from open and tall eucalypt forest to low and dense pine stands. Crowning potential is nil for six forest types, and the likelihood of crown fire increases by a factor of 2.4 from dense and tall eucalypt plantations to Acacia woodland and dense and low $P$. pinaster.

Inspection of Figure 1 suggests that flammability is a function of stand structure, rather than of cover type. This contradicts simplistic but frequent assertions that are made about the hazard posed by certain vegetation types, and is readily apparent for the most widespread species (Pinus pinaster, Eucalyptus globulus, Quercus suber). The potential for surface fire spread and intensity respectively vary 7 - and 6-fold within $P$. pinaster types, 10- and 9-fold in eucalypt plantations, and 7- and 5-fold in $Q$. suber stands. All three species include at least a structural variant - open and tall in the case of pines and eucalypts, and tall (dense or open) in the case of $Q$. suber - which is not prone to crown fire. Fire potential descriptors, stand variables and most fuel descriptors are in fact not statistically different $(p>0.05)$ between cover types. Significant differences between fuel variables are indicated in Table II. $P$. pinaster fuel models are significantly higher $(p<0.05)$ in heat content and moisture of extinction due to their litter and understorey shrub species characteristics. Understorey height and live fuel moisture tend to be higher in deciduous Quercus. Heat content is the single variable showing some discrimination between cover types, but this is of minor relevance to flammability, because heat content range of variation is narrow (Tab. I).

Table III summarizes stand, fuel and fire hazard descriptors for each type of forest structure, reinforcing and helping to understand the impression left by Figure 1 in that structure is more relevant to fire hazard than cover type. Open structures have a lower and less expressive understorey layer and less fuel loading. This challenges the usual belief, and probably reflects the fuel dynamics associated to stand development - younger eucalypt plantations and older stands are included - and the type of management and environmental constraints that southern Portugal woodlands of $Q$. suber and $Q$. rotundifolia (the species that dominate open and low diverse woodland) are subjected to. The height of understorey vegetation decreases with stand height $(p=0.030)$ and with crown base height $(p=0.0214)$, and the same trend is shown by understorey cover but it is significant ( $p=0.0096$ ) for crown base height only.

Open and low stands have drier dead fuel and are more exposed to wind, showing the highest potential for fire spread. Tall stands have higher crown base as expected, which greatly reduces crown fire hazard. The high and low extremes of the 
Table IV. Explanation $\left(R^{2}\right)$ of fire behavior variation and relative importance $(\beta$, standardized regression coefficients) of the independent variables.

\begin{tabular}{lccc}
\hline Fire variable & $R^{2}$ & & Independent variables $(p<0.05), \beta$ \\
\hline Rate of spread & 0.89 & WAF, 0.62 & Fuel depth, 0.34 \\
Fireline intensity & 0.85 & Fuel load, 0.94 & Rate of spread, 0.85 \\
Crowning potential & 0.88 & Crown base height, -0.59 & Fireline intensity, 0.45 \\
\hline
\end{tabular}

Md = moisture content of fine dead fuel.

surface fire intensity and crown fire potential spectrum are understandably occupied by dense and low stands and tall open forests, understorey development and fuel accumulation being superior in the former; the spread potential is nevertheless similar between these two structural types, which do not differ in their wind adjustment factors and dead fuel moisture contents.

An analysis of the relative importance of fuel and weather variables on fire hazard further helps to understand variation in fire potential and is interesting to define fuel management guidelines and priorities. Fire behaviour estimates were regressed on the fire environment variables by linear least squares - our limited sample size of $n=19$ does not warrant a more sophisticated approach - and standardized regression coefficients $(\beta)$ used to express the weight of each significant $(p<0.05)$ factor (Tab. IV). Variation in rate of fire spread is dominated by the WAF, with a comparatively minor influence of fuel depth and dead fuel moisture content. The influence of fuel load prevailed over rate of spread in regards to fireline intensity, and crown base height was more important than fireline intensity in explaining variation in crowning potential. The relevance of describing surface fuel as accurately as possible is obviously downplayed by the weight in estimated fire behaviour of variables related with stand structure (WAF, dead fuel moisture content, crown base height). The following is inferred from these results: (i) the increasing effect exerted on fire spread by stand thinning and pruning via changes in within-stand wind movement and dead fuel moisture; (ii) the strong role of surface fuel treatment in limiting fire intensity, hence favouring the effectiveness of fire suppression and decreasing fire severity; and (iii) the relevance of achieving vertical discontinuity in order to avoid crown fire. A paradox arises, because interventions in the canopy are crucial to minimize crown fire development but can exacerbate the surface fire potential. The major implication is that surface fuel treatment should be a prerequisite to operations of canopy fuel modification (Agee and Skinner, 2005; Graham et al., 2004).

At this point the individual fire hazard scores of each forest type can be subjectively qualified as low (0-24), moderate (25-49), high (50-74) or very high (75-100). Four basic hazard groups emerge from the cluster analysis on the three fire hazard scores, from the lowest to the highest fire potential:

1. Open and tall forest types, and closed and tall $Q$. suber and diverse forests (mostly P. pinea, P. sylvestris, Castanea sativa and deciduous oaks). Surface fuel accumulation is low to moderate and the canopy layer is distant from the ground. Fireline intensity is low and the potential for crown fire development is nil, although rate of spread varies (low to high potential).
2. Closed, low woodlands of deciduous oaks, $Q$. suber and diverse forests $(Q$. rotundfolia, $P$ pinea, $P$. sylvestris, $C$. sativa, among others), closed and tall $P$. pinaster forest, and tall (either open or dense) E. globulus stands. This is the group with more heterogeneous fuel conditions, especially in understorey cover and fuel loading. Surface fire potential is moderate. Crowning potential is high or very high, but in dense pine and eucalypt stands is only moderate.

3. Open and low forest types. The spread and crowning hazards are very high, due to wind exposure and near-total vertical continuity. With a fuel loading similar to group 1 , albeit in a more flammable arrangement, surface fire intensity ranges from moderate to high.

4. Closed and low stands of P. pinaster, E. globulus and Acacia spp. Spread rate is only moderate, but fireline intensity is high or very high due to a well-developed shrub layer and high fuel loading. The highest vertical continuity among groups contributes to an extreme crowning potential.

Figure 2 illustrates the fire hazard groups. The above categorization agrees with expert knowledge (González et al., 2007b) and with observation of the effects of forest composition and structure on burn probability and severity. Deciduous forests - classified here in fire hazard groups 1 and 2 - burn less than expected in relation to their availability in the landscape, in NW Portugal (Moreira et al., 2001) and elsewhere (Cumming, 2001), and experience lower fire severity than the conifer stands in their vicinity (Choung et al., 2004; Hély et al., 2003; Wang, 2002). The burn probability of closed and low deciduous stands (included in group 2) in Portugal decreases with their patch size (Godinho-Ferreira et al., 2006), which is suggestive of an unfavourable environment for fire spread. A model developed by González et al. (2006) for Catalonia, Spain, indicates a decreased probability of wildfire in stands with higher mean tree diameter, lower basal area and less variable tree diameter (i.e. higher vertical discontinuity), structural characteristics that are consistent with our fire hazard group 1. A growing body of North-American literature is also providing empirical evidence that open and tall conifer forests are less vulnerable to fire (Agee and Skinner, 2005; Lentile et al., 2006; Pollet and Omi, 2002).

Godinho-Ferreira et al. (2005) present a tentative map for the distribution of each forest type and quantify their respective areas, allowing estimation of the relative importance of each fire hazard condition: groups $1,2,3$ and 4 respectively occupy $19.3 \%, 41.0 \%, 21.7 \%$ and $18.0 \%$ of the forested Portuguese area. Fire hazard distribution within 
(a)

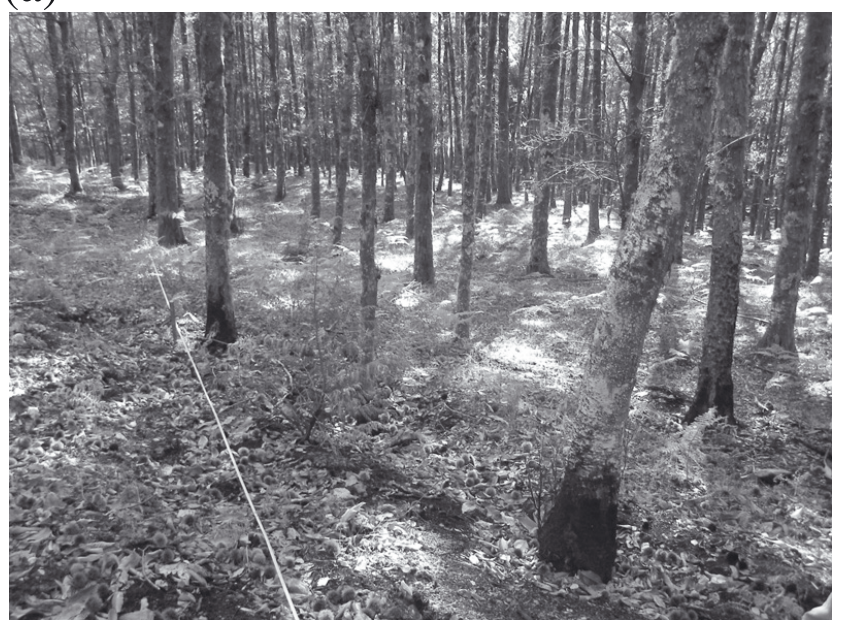

(c)



(e)



(b)

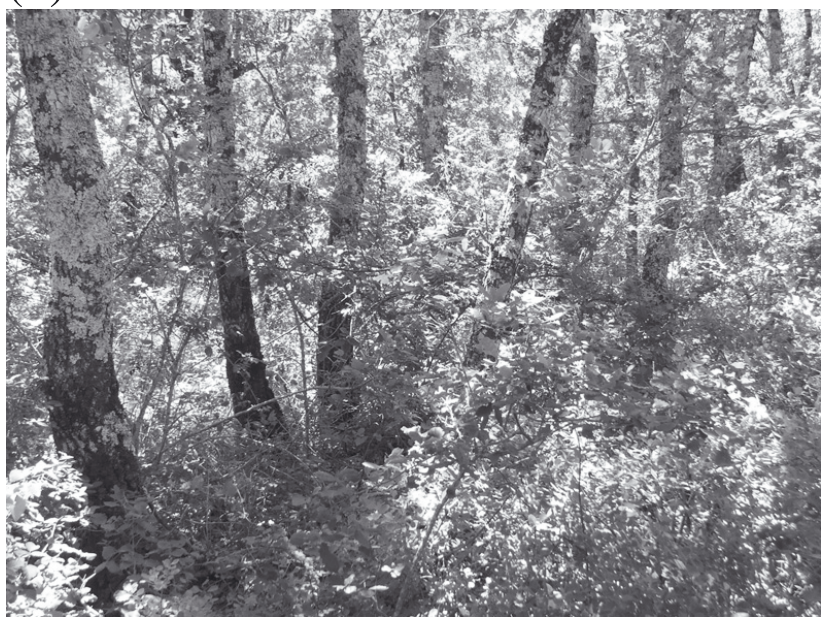

(d)



(f)

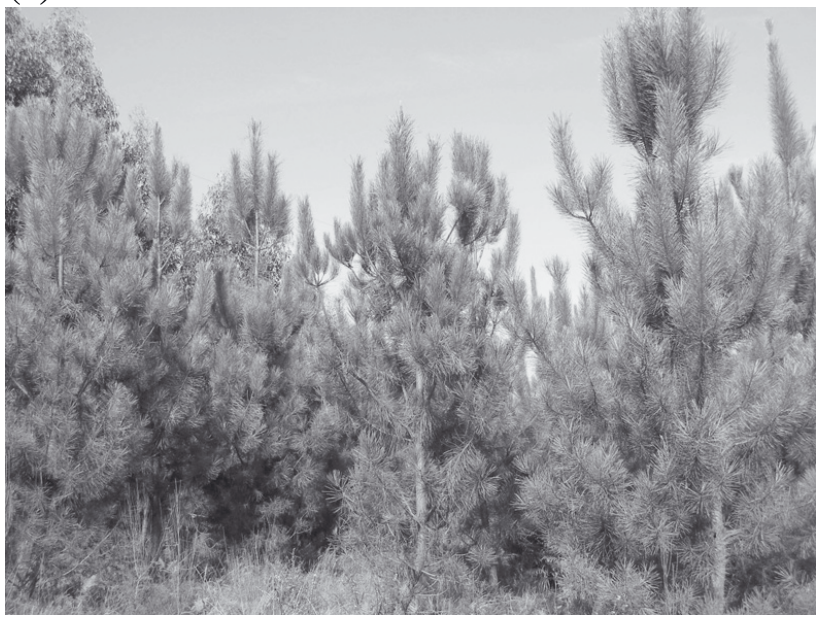

Figure 2. Illustration of the fire hazard groups: (a) Group 1, fire self-extinction in a CT mixed stand of Betula celtiberica and Castanea sativa; (b) Group 2, CL Quercus faginea; (c) Group 2, CT Pinus pinaster; (d) Group 2, Eucalyptus globulus; (e) Group 3, OL Quercus suber; (f) Group 4, CL P. pinaster. 
large fires, the relationship between the average hazard condition within burned areas and fire size, or an assessment of how burn severity varies with fire hazard could be used to verify the results of this study. Cartographical representations on an adequate scale of the fire hazard associated to each structural forest type would pave the way to analyse the effectiveness and trade-offs of distinct scenarios of stand and fuel management and cover type replacement. For instance, for a given typical regional landscape the relative change in burned surface and fire severity could be examined as a function of alternative spatial configuration of preferred, less flammable fuel types, by taking advantage of the capabilities of fire growth simulation software (Finney, 1998).

\section{CONCLUSION}

A coherent fire hazard assessment for forest types defined as a combination of overstorey species dominance and stand structure resulted from a fuel modelling approach based on relatively simple forest inventory data. The methodology served well the goal of comparing the relative fire hazard potential of Portuguese forest types on a quantitative and objective basis. A major implication of the results is that fire hazard cannot be inferred automatically from forest composition, as the range in fire potential was similar between and within cover types.

Stand structure is in most instances more important to fire behaviour than the tree species that comprise the stand. Individual descriptors of stand structure and the general four structural types (closed, low or tall; open, low or tall) show some correlation with surface fuel characteristics, have a strong influence on in-stand wind speed and dead fuel moisture, and are critical in the transition of surface to crown fire. This places the emphasis on fuel and stand dynamics and, consequently on proactive stand and fuel management. The fire hazard represented by dry and potentially flammable cover types (pines, eucalypts, sclerophyllous oaks) therefore varies with the type and intensity of management they are subjected to.

The availability of fuel models describing relevant vegetation types can support decision-making improvements in both planning and operational fire situations. The results of the effort undertaken in this study are a baseline for future developments that will hopefully lead to a wide-ranging and flexible fuel modelling classification for Portugal.

Acknowledgements: Fundação para a Ciência e Tecnologia (FCT) funded this study through projects "Development of fuel models to appraise fire hazard in Portuguese wildland areas" (POCI/AGR/61164/2004) and "PHOENIX - Forest conversion in burned areas" (POCI/AGR/58896/2004). Paulo Godinho-Ferreira supplied data resulting from the NFI analysis.

\section{REFERENCES}

Agee J.K. and Skinner C., 2005. Basic principles of forest fuel reduction treatments. For. Ecol. Manage. 211: 83-96.
Alexander M., 2007. Simple question; difficult answer: how much fuel is acceptable? Fire Management Today 67: 6-11.

Allgöwer B., Harvey S., and Rüegsegger M., 1998. Fuel models for Switzerland: description, spatial pattern, index for torching and crowning. In: Viegas D.X. (Ed.), Proc. 3rd International Conference on Forest Fire Research \& 14th Fire and Forest Meteorology Conference, ADAI, Coimbra, pp. 2605-2620.

Allgöwer B., Calogine D., Camia A., Cuiñas P., Fernandes P., Francesetti A., Hernando C., Kötz B., Koutsias N., Lindberg H., Molina D., Morsdorf F., Ribeiro L., Rigolot E., and Séro-Guillaume O., 2004. Methods for wildland fuel description and modeling: a state of the art, Deliverable D-02-01, EUFIRELAB: Euro-Mediterranean Wildland Fire Laboratory, a "wall-less" Laboratory for Wildland Fire Sciences and Technologies in the Euro-Mediterranean Region, Contract No. EVR1-CT-2002-40028.

Anderson H.E., 1982. Aids to determining fuel models for estimating fire behaviour, USDA Forest Service, Ogden, 22p.

Andrews P., Bevins C., and Seli R., 2005. BehavePlus Fire Modeling System, version 3.0: user's guide, USDA Forest Service, Ogden, $134 \mathrm{p}$.

Bachmann A. and Allgöwer B., 2000. The need for a consistent wildfire risk terminology. In: Gollberg G.E. (Ed.), Crossing the millenium: integrating spatial technologies and ecological principles for a new age in fire management, University of Idaho and International Association of Wildland Fire, Boise, pp. 67-77.

Brown J.K., 1981. Bulk densities of nonuniform surface fuels and their application to fire modeling. For. Sci. 27: 667-683.

Burgan R. and Rothermel R., 1984. BEHAVE: fire behavior prediction and fuel modeling system - FUEL subsystem, USDA Forest Service, Ogden, 137p.

Byram G.M., 1959. Combustion of forest fuels. In: Davis K.P. (Ed.), Forest fire: control and use, McGraw-Hill, New York, pp. 90-123.

Castro F.X., Tudela A., Gabriel E., Montserrat D., Canyameros E., and Segarra M., 2006. Evolution of live fuel moisture in Mediterranean forests. In: Viegas D.X. (Ed.), Proceedings V International Conference on Forest Fire Research, Elsevier B.V., CDROM, Amsterdam.

Choung Y., Lee B., Cho J., Lee K., Jang I., Kim S., Hong S., Jung H., and Choung H., 2004. Forest responses to the large-scale east coast fires in Korea. Ecol. Res. 19: 43-54.

Cohen M., Cuiñas P., Diez C., Fernandes P., Guijarro M., and Moro C., 2003. Wildland fuel particles characterization database content, Deliverable D6-03-A1, Fire Star: a decision support system for fuel management and fire hazard reduction in Mediterranean wildland urban interfaces, Contract No. EVG1-CT-2001-00041.

Countryman C., 1974. Can Southern California Wildland Conflagrations be Stopped? USDA Forest Service, Berkeley, 11 p.

Cruz M.G., 2005. Guia fotográfico para identificação de combustíveis florestais - região Centro de Portugal, CEIF, ADAI, Coimbra. 26p.

Cruz M.G., Alexander M.E., and Wakimoto R.H., 2003. Assessing canopy fuel stratum characteristics in crown fire prone fuel types of western North America. Int. J. Wildl. Fire 12: 39-50.

Cruz M.G. and Fernandes P.M, 2008. Development of fuel models for fire behaviour prediction in maritime pine (Pinus pinaster Ait.) stands. Int. J. Wildl. Fire 17: 194-204.

Cumming S.G., 2001. Forest type and wildfire in the Alberta boreal mixedwood: what do fires burn? Ecol. Appl. 11: 97-110.

DGF, 2001. Inventário Florestal Nacional: Portugal Continental $3^{\mathrm{a}}$ revisão, DGF, Lisboa.

DGRF, 2006. Incêndios florestais, relatório de 2005, Divisão de Defesa da Floresta Contra Incêndios, DGRF, Lisboa. 
Dimitrakopoulos A.P., 2002. Mediterranean fuel models and potential fire behaviour in Greece. Int. J. Wildl. Fire 11: 127-130.

Fernandes P.M. and Botelho H.S., 2003. A review of prescribed burning effectiveness in fire hazard reduction. Int. J. Wildl. Fire 12: 117-128.

Fernandes P.M. and Botelho H.S., 2004. Analysis of the prescribed burning practice in the pine forest of northwestern Portugal. J. Env. Manage. 70: 15-26.

Fernandes P.M. and Rigolot E., 2007. Fire ecology and management of maritime pine (Pinus pinaster Ait.). For. Ecol. Manage. 241: 1-13.

Finney M., 1998. FARSITE: Fire Area Simulator - model development and evaluation. USDA Forest Service, Ogden, $47 \mathrm{p}$.

Godinho-Ferreira P., Azevedo A., and Rego F., 2005. Carta da tipologia florestal de Portugal Continental. Silva Lusitana 13: 1-34.

Godinho-Ferreira P., Azevedo A., Vaz P., and Rego F., 2006. Composition, configuration and vertical structure of Portuguese forests: implications in wildfire probability. In: Viegas D.X. (Ed.), Proceedings V International Conference on Forest Fire Research, Elsevier B.V., Amsterdam, CD-ROM.

González J.R., Palahí M., Trasobares A., and Pukkala T., 2006. A fire probability model for forest stands in Catalonia (north-east Spain). Ann. For. Sci. 63: 169-176.

González J.R., Trasobares A., Palahí M., and Pukkala T., 2007a. Predicting stand damage and tree survival in burned forests in Catalonia (North-East Spain). Ann. For. Sci. 64: 733-742.

González J.R., Kolehmainen O., and Pukkala T., 2007b. Using expert knowledge to model forest stand vulnerability to fire. Comput. Electron. Agric. 55: 107-114.

Graham R., McCaffrey S., and Jain T., 2004. Science basis for changing forest structure to modify wildfire behavior and severity, USDA Forest Service, Fort Collins, 43 p.

Hardy C.C., 2005. Wildland fire risk and hazard: problems, definitions and concepts. For. Ecol. Manage. 211: 73-82.

Hardy C.C., Schmidt K.M., Menakis J.P., and Sampson R.N., 2001. Spatial data for national fire planning and fuel management. Int. J. Wildl. Fire 10: 353-372.

Hély C., Flannigan M., and Bergeron Y., 2003. Modeling tree mortality following wildfire in the Southeastern Canadian mixed-wood boreal forest. For. Sci. 49: 566-576.

Hirsch K.G. and Martell D.L., 1996. A review of initial attack fire crew productivity and effectiveness. Int. J. Wildl. Fire 6: 199-215.
Hough W.A. and Albini F.A., 1978. Predicting fire behavior in palmettogalberry fuel complexes, USDA Forest Service, Asheville, $44 \mathrm{p}$.

ICONA, 1990. Clave fotografica para la identificación de modelos de combustible, Defensa contra incendios forestales, MAPA, Madrid.

Johnson R.A. and Wichern D.W., 1982. Applied multivariate statistical analysis, Prentice-Hall Inc., New Jersey, 800 p.

Lentile L.B., Smith F.W., and Shepperd W.D., 2006. Influence of topography and forest structure on patterns of mixed severity fire in ponderosa pine forests of the South Dakota Black Hills, USA. Int. J. Wildl. Fire 15: 55

Moreira F., Rego F., and Ferreira P.G., 2001. Temporal (1958-1995) pattern of change in a cultural landscape of northwestern Portugal: implications for fire occurrence. Land. Ecol. 16: 557-567.

Pollet J. and Omi P.N., 2002. Effect of thinning and prescribed burning on crown fire severity in ponderosa pine forests. Int. J. Wildl. Fire 11: $1-10$.

Rothermel R.C., 1972. A mathematical model for predicting fire spread in wildland fuels, USDA Forest Service, Ogden, $40 \mathrm{p}$.

Rothermel R.C., Wilson R.A., Morris G.A., and Sackett S.S., 1986. Modeling moisture content of fine dead wildland fuels, USDA Forest Service, Ogden, 61 p.

Sandberg D.V., Ottmar R.D., and Cushon G.H., 2001. Characterizing fuels in the 21st century. Int. J. Wildl. Fire 10: 381-387.

Scott J.H. and Reinhardt E.D., 2001. Assessing crown fire potential by linking models of surface and crown fire behavior. USDA Forest Service, Fort Collins, 59 p.

Silva T., Pereira J.C., Paúl J., Santos M.N., and Vasconcelos M.P., 2006. Estimativa de emissões atmosféricas originadas por fogos rurais em Portugal. Silva Lusitana 14: 239-263.

Van Wagner C., 1977. Conditions for the start and spread of crown fire. Can. J. For. Res. 3: 373-378.

Viegas D.X., Viegas M.T., and Ferreira A.D., 1992. Moisture content of fine forest fuels and fire occurrence in Central Portugal. Int. J. Wildl. Fire 2: 69-86.

Viegas D.X., Piñol J., Viegas M.T., and Ogaya R., 2001. Estimating live fine fuels moisture content using meteorologically-based indices. Int. J. Wildl. Fire 10: 223-240.

Wang G.G., 2002. Fire severity in relation to canopy composition within burned boreal mixedwood stands. For. Ecol. Manage. 163: 85-92. 